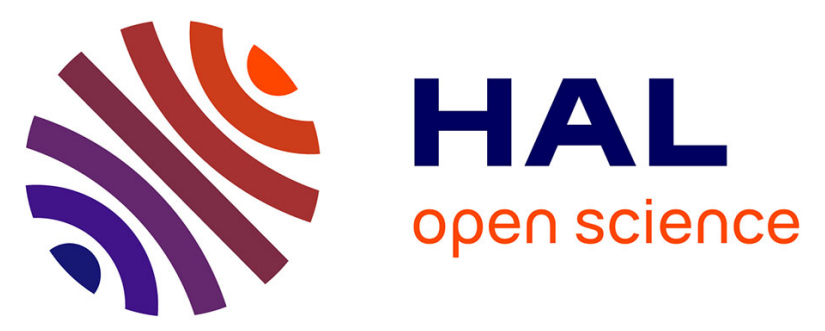

\title{
Spatial patterns of benthic invertebrate assemblages within atoll lagoons: importance of habitat heterogeneity and considerations for marine protected area design in French Polynesia
}

Eric Pante, Mehdi Adjeroud, Lucie Penin, Phil Dustan, Muriel Schrimm

\section{To cite this version:}

Eric Pante, Mehdi Adjeroud, Lucie Penin, Phil Dustan, Muriel Schrimm. Spatial patterns of benthic invertebrate assemblages within atoll lagoons: importance of habitat heterogeneity and considerations for marine protected area design in French Polynesia. Aquatic Living Resources, 2006, 19, pp.207-217. 10.1051/alr:2006021 . hal-00935865

\section{HAL Id: hal-00935865 \\ https://hal.science/hal-00935865}

Submitted on 24 Jan 2014

HAL is a multi-disciplinary open access archive for the deposit and dissemination of scientific research documents, whether they are published or not. The documents may come from teaching and research institutions in France or abroad, or from public or private research centers.
L'archive ouverte pluridisciplinaire HAL, est destinée au dépôt et à la diffusion de documents scientifiques de niveau recherche, publiés ou non, émanant des établissements d'enseignement et de recherche français ou étrangers, des laboratoires publics ou privés. 


\title{
Spatial patterns of benthic invertebrate assemblages within atoll lagoons: importance of habitat heterogeneity and considerations for marine protected area design in French Polynesia
}

\author{
Eric Pante ${ }^{1,2}$, Mehdi Adjeroud ${ }^{2, a}$, Phillip Dustan $^{1}$, Lucie Penin $^{2}$ and Muriel Schrimm ${ }^{2}$ \\ ${ }^{1}$ College of Charleston, 58 George Street, Charleston SC 29412, USA \\ 2 Centre de Biologie et d'Écologie Tropicale et Méditerranéenne, École Pratique des Hautes Études, Laboratoire «Ecosystèmes Aquatiques \\ Tropicaux et Méditerranéens », UMR CNRS-EPHE 8046, Université de Perpignan, Avenue Paul Alduy, 66860 Perpignan Cedex, France \\ and Centre de Recherches Insulaires et Observatoire de l'Environnement, BP 1013 Papetoai, Moorea, French Polynesia
}

Received 11 April 2006; Accepted 17 July 2006

\begin{abstract}
We investigated spatial patterns of stony corals, molluscs and echinoderms among six habitat types within the lagoons of six atolls in the Tuamotu Archipelago (French Polynesia). Percent cover (stony corals only), abundance and richness were recorded within habitat types delineated by specific geomorphological features. Among six habitat types defined a priori, four encompassed distinct assemblages of corals and molluscs: (1) pinnacles possessed maximum richness, abundance and coverage, (2) passes showed relatively high abundance and coverage, (3) lagoon floors were marked by the commonness of a few coral genera, and minimum mollusc abundance and richness, and (4) inner reef flat stations, independent of their location in front of spillways, motu or rim zones, had low cover, abundance, and richness. While habitat associations were similar for stony corals and molluscs, echinoderms were preferentially found on the inner reef flat facing the rim. Lowest echinoderm abundances and species richness were recorded on pinnacles and in the vicinity of the pass. Such small-scale spatial heterogeneity appears to be one of the distinctive characteristics of coral communities in French Polynesian reefs. These results, along with those of the TYPATOLL program, demonstrate the importance of both local and regional factors in determining the diversity and structure of coral assemblages. Habitat fidelity was weak: many species/genera were poorly represented among habitats and restricted to a few atolls, while others were present across all lagoons and habitats. Therefore, marine protected areas design based solely on representativeness will require the protecting the vast majority of lagoon habitats.
\end{abstract}

Key words: Coral reefs / Community structure / Reef habitats / Spatial scale / Marine protected area / Reserve design

Résumé - Structuration spatiale des assemblages d'invertébrés benthiques dans les lagons d'atoll : importance de l'hétérogénéité de l'habitat et considérations pour la mise en ouvre d'aires marines protégées en Polynésie française. Nous avons examiné l'organisation spatiale des coraux, mollusques et échinodermes dans six lagons d'atoll de l'archipel des Tuamotu (Polynésie française). Le pourcentage de recouvrement (coraux uniquement), l'abondance et la diversité ont été mesurés dans des sites géomorphologiquement contrastés. Parmi les six habitats lagonaires définis a priori, quatre sont distincts pour les coraux et les mollusques : (1) l'abondance, la diversité et le recouvrement maximaux sont enregistrés aux stations de pinacle, (2) le recouvrement et l'abondance sont relativement élevés aux stations de passe, (3) les stations de fond de lagons sont caractérisées par la présence de quelques genres de coraux caractéristiques, et des valeurs d'abondance minimales pour les mollusques, et (4) les stations du platier récifal, quelle que soit leur localisation (face aux hoa, motu, ou couronne), sont caractérisées par des valeurs de recouvrement, d'abondance et de diversité particulièrement faibles. Alors que l'organisation spatiale des coraux et des mollusques est similaire, celle des échinodermes diffère. Ces derniers sont plus abondants sur le platier récifal, et sont peu représentés aux stations de passe et sur les pinacles. Cette forte hétérogénéité spatiale, au sein des lagons d'atoll, complète celle observée pour les îles hautes volcaniques de Polynésie française, ainsi que la variation inter-atoll décrite à l'échelle régionale dans l'archipel des Tuamotu. L'hétérogénéité spatiale à petite échelle apparait être un caractère distinctif des communautés benthiques en Polynésie française. Les résultats de cette étude complètent ceux du programme TYPATOLL et démontrent l'importance des facteurs locaux et régionaux dans la structure spatiale et la diversité locale des communautés coralliennes. Un grand nombre de genres/espèces sont limités à quelques habitats et ne colonisent que certains lagons d'atoll, tandis que d'autres sont ubiquistes et sont présents dans la plupart des habitats et des lagons. Si préserver la biodiversité des lagons d'atoll est l'objectif principal des gestionnaires de l'environnement, la mise en œuvre d'aires marines protégées dans ces biotopes nécessite par conséquent la protection de l'ensemble des habitats lagonaires.

\footnotetext{
${ }^{a}$ Corresponding author: adjeroud@univ-perp.fr
} 


\section{Introduction}

Recent studies showed that atoll lagoons may support highly diverse benthic communities and are therefore areas of interest for marine conservation (Vroom et al. 2005; Kenyon et al. 2006). One of the fundamental goals of marine protected areas (MPAs) is to sustain and protect biological diversity (e.g., Agardy 1994). Effective MPA design requires knowledge of habitat delineation and the identification of homogeneous communities within a relatively heterogenous landscape (Stevens 2002, 2005). Additionally, accounting for connectivity between protected and non-protected communities is important to allow for larval replenishment and the "rescue effect" (Agardi 1994; Holland and Brazee 1996; Roberts et al. 2003a, 2003b; Stevens 2005).

In French Polynesia, the conservation of atoll lagoons located in close proximity to human population centers poses a particular challenge because they are discrete and fragile ecosystems which are relied on heavily for their biological resources and ecosystem services (Vieux et al. 2004). As habitat representation and the delineation of homogeneous landscapes is critical in designing marine reserves, the geomorphological variety that exists both among and within atolls (Adjeroud et al. 2000) justifies the study of the distribution of lagoonal communities at these nested spatial scales. While population connectivity must be taken into consideration during the design of marine reserves (Odgen 1997; Roberts 1997), its incorporation in modeling and marine conservation is still in its infancy (Roberts 1998; Sala 2002; Gerber et al. 2003). The diversity of atoll geomorphology and magnitude of oceanic influence increases the difficulty of the already challenging task of determining the origin of source populations and regional patterns of connectivity. This investigation of the spatial structure of benthic invertebrate communities at nested spatial scales may lay the ground work for future research on the extent of connectivity within a network of atoll lagoons.

The 77 atolls of the Tuamotu Archipelago comprise 18\% of the world's atolls (Chevalier and Denizot 1979; Bouchon 1983; Salvat 1983). They display an extraordinary diversity of geomorphological features, and thus represent a unique system for examining the structure and ecology of lagoon communities. Resource protection awareness emerged in the 1970s in French Polynesia after signs of reef degradation were recorded near populated areas (Salvat and Aubanel 2002; Vieux et al. 2004). In the Tuamotu Archipelago, the privately owned atoll of Taiaro was declared a UNESCO "Man and Biosphere" reserve in 1977 (Hutchings et al. 1994). The French Polynesian Government is concerned by the development of the pearl industry in atolls of the archipelago, and plans exist to geographically expand the Taiaro reserve to encompass six other atolls: Aratika, Kauehi, Niau, Raraka, Toau and Fakarava (Vieux et al. 2004).

"TYPATOLL", a multidisciplinary program, was initiated to understand the structure and functioning of atoll lagoons of the central part of the Tuamotu (Dufour and Harmelin-Vivien 1997). The first results from TYPATOLL focused on regional scale variation (i.e., analyses of variation among lagoons), pointing out the important role of an atoll's physical properties (surface area and depth of the lagoon, degree of hydrodynamic aperture, etc.) in the differentiation of its macrobenthic communities (Adjeroud et al. 2000), but did not investigate intra-lagoon variability. As MPA implementation begins to develop in the Tuamotu, the need for habitat delineation increases. Whereas Taiaro is a unique, closed atoll that is likely to have a limited role in a network of protected atolls, the atolls investigated during the TYPATOLL expedition, among them Kauehi, are more open systems. We used TYPATOLL datasets from six atolls to examine the spatial distribution of benthic invertebrate assemblages (scleractinian corals and Millepora, molluscs, echinoderms) across stations of different lagoonal origin. Our objectives were to examine (1) the variability of diversity and abundance, percent cover, and generic/species composition of benthic invertebrate assemblages across habitats within atoll lagoons, and (2) determine which habitats should be of particular concern when designing MPAs, based on biological criteria such as genera/species representativeness and co-occurrence.

\section{Materials and methods}

\subsection{Sampling}

The Tuamotu Archipelago, one of the five archipelagos in French Polynesia, lies in the eastern Indo-Pacific province, and contains 77 of the 425 atolls existing worldwide. Six atolls were surveyed during this study: Haraiki, Hiti, Kauehi, Marokau, Nihiru and Tepoto Sud (Fig. 1). Their main physical and geomorphological characteristics are presented (Table 1).

Within atoll lagoons, a total of six different potential habitats were distinguished during the sampling design of the TYPATOLL program (Dufour and Harmelin-Vivien 1997): (1) the inner reef flat in front of submerged reef flats (referred as the "rim"; R); (2) the inner reef flat in front of the emergent rim (referred as the "motu"; M); (3) the inner reef flat in front of hoas (spillways in Tuamotu language; $\mathrm{H}$ ); (4) passes (PA); (5) pinnacles or knolls (defined as hard substrate rising from the lagoon floor to near the water surface; P); (6) the lagoon floor $(\mathrm{F})$. The distinction of these six habitats was made according to their geomorphological, hydrological, and hydrodynamic characteristics. Within each of the six habitats, two stations were established (Fig. 1). The number of sampling stations varied between atolls according to the existence of each of these habitats (Fig. 1). Stations will be cited using the following abbreviation: first two letters of the atoll's name, first one or two letters of the habitat, and the station number.

Observations were carried out by SCUBA diving or snorkelling, between September and October 1996. All coral colonies (orders Milleporina and Scleractinia) larger than $1 \mathrm{~cm}$ and visible without the need to move rocks, as well as visible echinoderms and molluscs, were identified and counted in $5 \mathrm{~m}^{2}$ quadrats $(2 \times 2.5 \mathrm{~m})$. For the first four habitats (R, M, H, PA), stations consisted of 16 quadrats arranged contiguously along a transect perpendicular to the shore, between 1 to $3 \mathrm{~m}$ depth. There is no differentiation of benthic invertebrate assemblages within this depth range on the inner reef flat of French Polynesian atolls (Chevalier and Denizot 1979; Bouchon 1983; Salvat 1983). The pass and hoa stations were located approximately $50 \mathrm{~m}$ to the right or left at the edge 

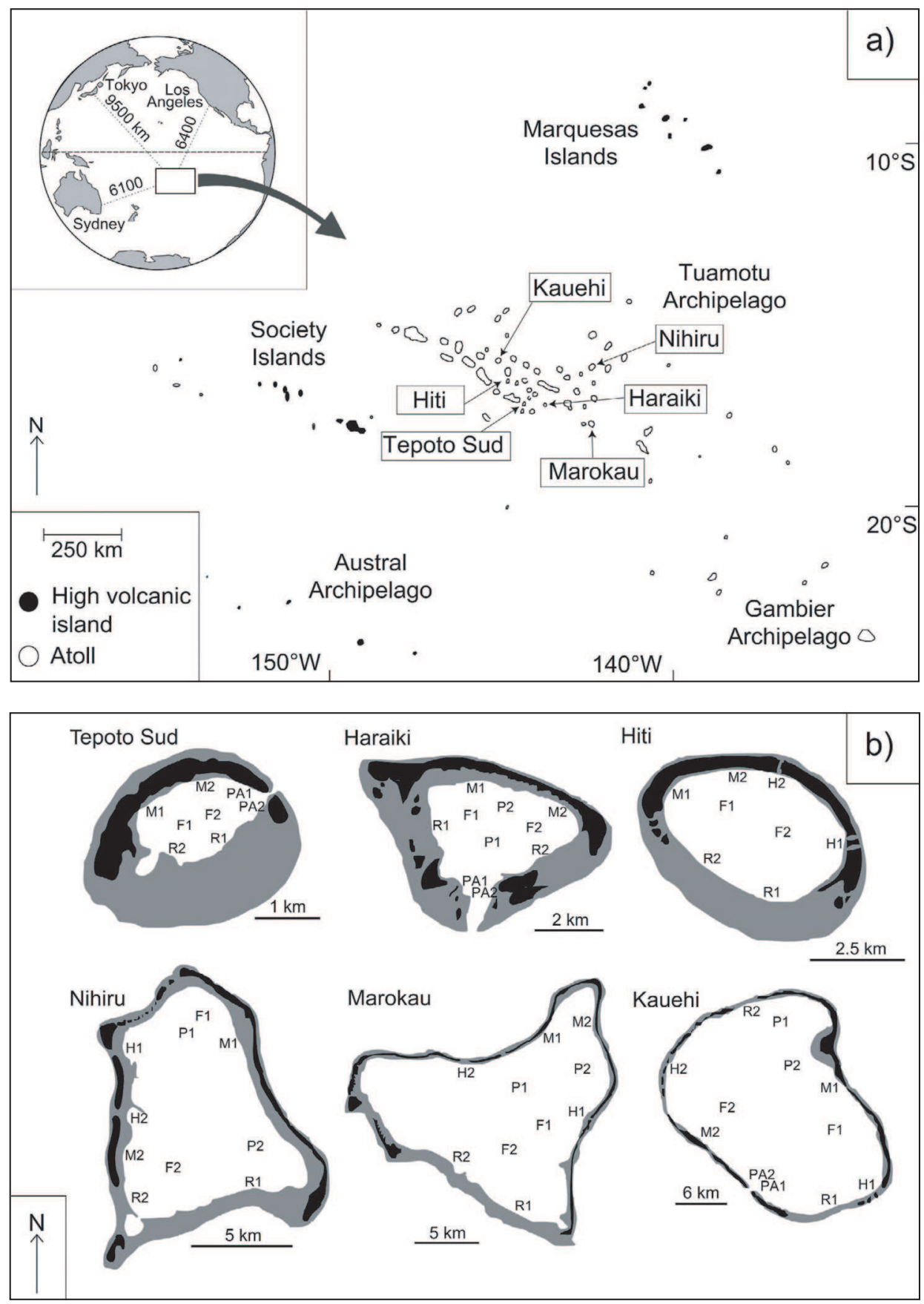

Fig. 1. Map of French Polynesia showing the location of the six atolls surveyed (a) and location of the 58 sampling stations in these six atoll lagoons (b). Station names are abbreviated as follow: first one or two letters of the habitat, R: Inner reef flat in front of submerged reef flat; M: Inner reef flat in front of the emergent R; H: Inner reef flat in front of spillways; PA: Pass; P: Pinnacles or knolls; F: Lagoon floor), and the station number. For each atoll, the emergent $\mathrm{R}$ is represented in black.

of the channels. The lagoon floor stations (F) were located at depths of $15 \mathrm{~m}$ for lagoons deeper than $15 \mathrm{~m}$, and close to the maximum depth for shallower lagoons (see Table 1 for lagoon average depth); each station consisted of eight contiguous quadrats. The pinnacle stations $(\mathrm{P})$ were sampled with four quadrats placed contiguously on the top of the pinnacle, and by four quadrats placed on their sides at approximately $3 \mathrm{~m}$ depth. Each atoll was sampled once during a three to five day period. Corals were identified at the genus level, given that several studies have shown that this level of identification is sufficient to discriminate coral assemblages among habitats at this spatial scale (McClanahan and Obura 1997; Rajasuriya et al. 1998). Molluscs and echinoderms were identified to species level. Three linear transects of $20 \mathrm{~m}$ were used at each station to estimate percent coral cover (Line Intercept Transect Method; Loya 1972). 
Table 1. Overview of the six atolls surveyed during this study. The relative proportion of each habitat type is presented as a percentage of the lagoon surface area (satellite data).

\begin{tabular}{|c|c|c|c|c|c|c|}
\hline & Tepoto Sud & Haraiki & Hiti & Nihiru & Marokau & Kauehi \\
\hline \multirow[t]{2}{*}{ Geographical coordinates } & $16^{\circ} 49^{\prime} \mathrm{S}$ & $17^{\circ} 28^{\prime} \mathrm{S}$ & $16^{\circ} 43^{\prime} \mathrm{S}$ & $16^{\circ} 41^{\prime} \mathrm{S}$ & $18^{\circ} 03^{\prime} \mathrm{S}$ & $15^{\circ} 50^{\prime} \mathrm{S}$ \\
\hline & $144^{\circ} 17^{\prime} \mathrm{W}$ & $143^{\circ} 26^{\prime} \mathrm{W}$ & $144^{\circ} 06^{\prime} \mathrm{W}$ & $142^{\circ} 50^{\prime} \mathrm{W}$ & $142^{\circ} 16^{\prime} \mathrm{W}$ & $145^{\circ} 09^{\prime} \mathrm{W}$ \\
\hline Human Population & 0 & 0 & 0 & 30 & 65 & 302 \\
\hline Atoll surface area $\left(\mathrm{km}^{2}\right)$ & 6.2 & 24.6 & 25 & 100 & 256 & 343 \\
\hline Lagoon surface area $\left(\mathrm{km}^{2}\right)$ & 1.6 & 10.4 & 15 & 80 & 217 & 315 \\
\hline Lagoon average depth (m) & 5 & 10 & 10 & 20 & 30 & 50 \\
\hline \multicolumn{7}{|c|}{ Percentage of lagoon surface area } \\
\hline Pass, PA & 2.4 & 0.1 & 0.0 & 0.0 & 0 & 0.1 \\
\hline Hoa, $\mathrm{H}$ & 0.0 & 0.0 & 0.1 & 0.7 & 0.7 & 1.0 \\
\hline Pinnacle, $\mathrm{P}$ & 0.0 & 0.8 & 0.0 & 2.3 & 1.1 & 0.1 \\
\hline Rim, R & 38.5 & 34.5 & 12.5 & 3.7 & 1.8 & 1.3 \\
\hline Motu, M & 39.4 & 34.8 & 13.9 & 15.5 & 6.7 & 12.3 \\
\hline Floor, F & 19.7 & 29.8 & 73.5 & 77.7 & 89.6 & 85.2 \\
\hline Number of stations & 8 & 10 & 8 & 10 & 10 & 12 \\
\hline
\end{tabular}

\subsection{Statistical analysis}

We compared the spatial variation in coral, echinoderm and mollusc generic richness and abundance and coral percent cover among six habitat types with Kruskal-Wallis tests (KW; $d f=5$ for all tests; transects/quadrats pooled across stations and lagoons). This nonparametric approach was used over an analysis of variance (ANOVA) because residuals were not normally distributed and variance groups were heterogeneous, even after transformation (Legendre and Legendre 1998). Additionally, post-hoc Mann-Whitney tests (MW) were performed to determine which pairs of habitats showed significant differences in generic richness, abundance and percent cover. Genera/species were categorized according to their occurrence across habitats, as following: occurs in 1-2 habitats: rare; 3-5 habitats: common; 6 habitats: ubiquitous. This categorization is independent to among-atoll lagoon variation.

The overall variation in composition and abundance of coral assemblages among stations was analysed using correspondence analysis computed from abundance community matrices (CA; Legendre and Legendre 1998). CA could not be performed for molluscs and echinoderms without omitting a large number of rare species, making interpretation difficult. Instead, corals, molluscs and echinoderms were grouped in a single matrix to examine variation in generic/species composition at a larger taxonomic scale (i.e. "macrobenthos").

Three co-occurrence indices were calculated from presence-absence matrices for all three taxonomic groups as well as the macrobenthos category to further support the interpretation of the CA and to provide an estimate of the level of community structure across stations (Gotelli 2000):

- The checkerboard score ("C-score"; Stone and Robert 1990) measures the degree of co-occurrence within the matrix. The larger the score, the less co-occurrence of species pairs (Haukisalmi and Henttonen 1998; Gotelli and Arnett 2000).

- The number of checkerboard species pairs ("Checker"; Diamond 1975) is the number of species pairs that never co-occur in the community matrix. The higher the Checker, the more competitively structured the community (Gotelli 2000; Gotelli and McGabe 2002).

- The number of unique species combinations ("Combo"; Pielou and Pielou 1968) is likely to be low within structured communities (Diamond 1975).

The three indices test for non-random patterns within the presence-absence community matrix. To test whether these indices were significantly different from what would be expected if occurrence was random (i.e., no community structure), original presence-absence matrices were randomized 5000 times, using a fixed-column sums and fixed-row sums randomization scheme (Gotelli 2000). The indices of co-occurrence were recalculated for each randomized matrix, forming a distribution, to which the original statistic was compared (Gotelli and Grave 1996; Gotelli 2000). To further emphasize the deviation of the statistics from random, Standardized Effect Size (SES) was calculated. The SES, scaled in units of standard deviation, is calculated as the difference between the observed index and the mean of simulated indices, divided by the standard deviation of the simulated indices (Gurevitch et al. 1992). Cooccurrence tests were performed using the software EcoSim (Gotelli and Entsminger 2006) and all other statistical tests were computed using R (R Development Core Team 2003). For all tests, a probability value less than 0.05 was considered statistically significant.

\section{Results}

\subsection{Stony corals}

A total of 24 genera were encountered within the 58 stations surveyed. Coral genera that occurred frequently across atolls were also frequent across habitats within those lagoons. Additionally, genera that were restricted to few habitats were also found within few lagoons (Table 2). Six genera were common to all lagoons, and 7 were widely distributed (recorded in five lagoons). Fungia was found in four lagoons 
Table 2. Presence-absence of corals, molluscs and echinoderms within the six different habitats (F: floor, H: hoa, M: motu, PA: pass, P: pinnacle, R: rim) investigated. "n. lagoons" refers to the number of lagoons in which species/genera were observed. For example, the coral Echinopora was found on floor stations (only) within two different lagoons.

\begin{tabular}{|c|c|c|c|c|c|c|c|}
\hline & $\mathbf{F}$ & $\mathbf{H}$ & $\mathbf{M}$ & $\mathbf{P A}$ & $\mathbf{P}$ & $\mathbf{R}$ & n. lagoons \\
\hline \multicolumn{8}{|l|}{ CORALS } \\
\hline Echinopora & $\mathrm{x}$ & & & & & & 2 \\
\hline Tubastrea & & & & & $\mathrm{x}$ & & 1 \\
\hline Dendrophyllia & & & & $\mathrm{x}$ & $\mathrm{x}$ & & 2 \\
\hline Leptoseris & $\mathrm{x}$ & & & $\mathrm{x}$ & & & 2 \\
\hline Palythoa & & & & $\mathrm{x}$ & $\mathrm{x}$ & & 1 \\
\hline Plesiastrea & $\mathrm{x}$ & & & & $\mathrm{x}$ & & 2 \\
\hline Herpolitha & $\mathrm{x}$ & & $\mathrm{x}$ & & $\mathrm{x}$ & & 1 \\
\hline Millepora & & & $\mathrm{x}$ & & $\mathrm{x}$ & $\mathrm{x}$ & 2 \\
\hline Montastrea & & & $\mathrm{x}$ & $\mathrm{x}$ & & $\mathrm{x}$ & 2 \\
\hline Fungia & $\mathrm{x}$ & $\mathrm{x}$ & $\mathrm{x}$ & & $\mathrm{x}$ & & 4 \\
\hline Stylocoeniella & $\mathrm{x}$ & $\mathrm{x}$ & $\mathrm{x}$ & & $\mathrm{x}$ & & 3 \\
\hline Pocillopora & & $\mathrm{x}$ & $\mathrm{x}$ & $\mathrm{x}$ & $\mathrm{x}$ & $\mathrm{x}$ & 5 \\
\hline Acanthastrea & $\mathrm{x}$ & $\mathrm{x}$ & $\mathrm{x}$ & $\mathrm{x}$ & $\mathrm{x}$ & $\mathrm{x}$ & 5 \\
\hline Acropora & $\mathrm{x}$ & $\mathrm{x}$ & $\mathrm{x}$ & $\mathrm{x}$ & $\mathrm{x}$ & $\mathrm{x}$ & 6 \\
\hline Astreopora & $\mathrm{x}$ & $\mathrm{x}$ & $\mathrm{x}$ & $\mathrm{x}$ & $\mathrm{x}$ & $\mathrm{x}$ & 5 \\
\hline Cyphastrea & $\mathrm{x}$ & $\mathrm{x}$ & $\mathrm{x}$ & $\mathrm{x}$ & $\mathrm{x}$ & $\mathrm{x}$ & 5 \\
\hline Favia & $\mathrm{x}$ & $\mathrm{x}$ & $\mathrm{x}$ & $\mathrm{x}$ & $\mathrm{x}$ & $\mathrm{x}$ & 6 \\
\hline Leptastrea & $\mathrm{x}$ & $\mathrm{x}$ & $\mathrm{x}$ & $\mathrm{x}$ & $\mathrm{x}$ & $\mathrm{x}$ & 6 \\
\hline Lobophyllia & $\mathrm{x}$ & $\mathrm{x}$ & $\mathrm{x}$ & $\mathrm{x}$ & $\mathrm{x}$ & $\mathrm{x}$ & 5 \\
\hline Montipora & $\mathrm{x}$ & $\mathrm{x}$ & $\mathrm{x}$ & $\mathrm{x}$ & $\mathrm{x}$ & $\mathrm{x}$ & 6 \\
\hline Pavona & $\mathrm{x}$ & $\mathrm{x}$ & $\mathrm{x}$ & $\mathrm{x}$ & $\mathrm{x}$ & $\mathrm{x}$ & 6 \\
\hline Platygyra & $\mathrm{x}$ & $\mathrm{x}$ & $\mathrm{x}$ & $\mathrm{x}$ & $\mathrm{x}$ & $\mathrm{x}$ & 5 \\
\hline Porites & $\mathrm{x}$ & $\mathrm{x}$ & $\mathrm{x}$ & $\mathrm{x}$ & $\mathrm{x}$ & $\mathrm{x}$ & 6 \\
\hline Psammocora & $\mathrm{x}$ & $\mathrm{x}$ & $\mathrm{x}$ & $\mathrm{x}$ & $\mathrm{x}$ & $\mathrm{x}$ & 5 \\
\hline \multicolumn{8}{|l|}{ MOLLUSCS } \\
\hline Conus pulicarius & & & & & & $\mathrm{x}$ & 1 \\
\hline Conus rattus & & & & & & $\mathrm{x}$ & 1 \\
\hline Cypraea moneta & & & $\mathrm{x}$ & & & & 1 \\
\hline Drupa grossularia & & & & $\mathrm{x}$ & & & 1 \\
\hline Drupa ricinus & & & & & $\mathrm{x}$ & & 1 \\
\hline Drupa rubusidaeus & & & & $\mathrm{x}$ & & & 1 \\
\hline Lambis truncata & $\mathrm{x}$ & & & & & & 1 \\
\hline Mancinella tuberosa & & & & & & $\mathrm{x}$ & 1 \\
\hline Mitra ferruginea & & & & & & $\mathrm{x}$ & 1 \\
\hline Peristernia nassatula & & & & & & $\mathrm{x}$ & 1 \\
\hline Spondylus varians & & & & & $\mathrm{x}$ & & 3 \\
\hline Conus lividus & & & & $\mathrm{x}$ & & $\mathrm{x}$ & 2 \\
\hline Conus miliaris & & & $\mathrm{x}$ & & & $\mathrm{x}$ & 2 \\
\hline Morula granulata & & & $\mathrm{x}$ & $\mathrm{x}$ & & & 2 \\
\hline Morula uva & & & $\mathrm{x}$ & $\mathrm{x}$ & & & 2 \\
\hline Pedum spondyloideum & & & $\mathrm{x}$ & & & $\mathrm{x}$ & 3 \\
\hline Pinctada margaritifera & $\mathrm{x}$ & & $\mathrm{x}$ & & & & 1 \\
\hline Strombus gibberulus & & $\mathrm{x}$ & & $\mathrm{x}$ & & & 2 \\
\hline Thais aculeatus & & $\mathrm{x}$ & & & $\mathrm{x}$ & & 1 \\
\hline Chama pacifica & $\mathrm{x}$ & & $\mathrm{x}$ & & $\mathrm{x}$ & & 2 \\
\hline Pinctada maculata & & $\mathrm{x}$ & $\mathrm{x}$ & & $\mathrm{x}$ & & 1 \\
\hline Pycnodonta hyotis & $\mathrm{x}$ & & $\mathrm{x}$ & & $\mathrm{x}$ & & 4 \\
\hline Cerithium echinatum & $\mathrm{x}$ & $\mathrm{x}$ & & $\mathrm{x}$ & $\mathrm{x}$ & & 5 \\
\hline Conus ebraeus & & $\mathrm{x}$ & $\mathrm{x}$ & $\mathrm{x}$ & & $\mathrm{x}$ & 3 \\
\hline Arca ventricosa & $\mathrm{x}$ & $\mathrm{x}$ & $\mathrm{x}$ & $\mathrm{x}$ & $\mathrm{x}$ & $\mathrm{x}$ & 5 \\
\hline Chama imbricata & $\mathrm{x}$ & $\mathrm{x}$ & $\mathrm{x}$ & $\mathrm{x}$ & $\mathrm{x}$ & $\mathrm{x}$ & 6 \\
\hline Tridacna maxima & $\mathrm{x}$ & $\mathrm{x}$ & $\mathrm{x}$ & $\mathrm{x}$ & $\mathrm{x}$ & $\mathrm{x}$ & 6 \\
\hline
\end{tabular}

Table 2. Continued.

\begin{tabular}{|c|c|c|c|c|c|c|c|}
\hline & $\mathbf{F}$ & $\mathbf{H}$ & $\mathbf{M}$ & $\mathbf{P A}$ & $\mathbf{P}$ & $\mathbf{R}$ & n. lagoons \\
\hline \multicolumn{8}{|l|}{ ECHINODERMS } \\
\hline Actynopyga mauritiama & & & & & $\mathrm{x}$ & & 1 \\
\hline Linckia multifora & & & $\mathrm{x}$ & & & & 1 \\
\hline Echinothrix diadema & & & & $\mathrm{x}$ & & $\mathrm{x}$ & 2 \\
\hline Bohadschia argus & & & & $\mathrm{x}$ & $\mathrm{x}$ & $\mathrm{x}$ & 4 \\
\hline Culcita novaeguineae & & & $\mathrm{x}$ & $\mathrm{x}$ & $\mathrm{x}$ & & 3 \\
\hline Echinothrix calamaris & & $\mathrm{x}$ & & $\mathrm{x}$ & & $\mathrm{x}$ & 3 \\
\hline Echinometra mathaei & & $\mathrm{x}$ & $\mathrm{x}$ & $\mathrm{x}$ & & $\mathrm{x}$ & 4 \\
\hline Holothuria atra & $\mathrm{x}$ & $\mathrm{x}$ & $\mathrm{x}$ & & $\mathrm{x}$ & $\mathrm{x}$ & 5 \\
\hline
\end{tabular}

and Stylocoeniella in three lagoons. Eight genera were restricted to one or two lagoons. Among habitat types, 6 genera were rare occurring in only one or two habitat types, whereas 6 genera were common and 12 were ubiquitously found among all six habitat types. Highest abundances (expressed as nb of colonies $\mathrm{m}^{-2}$; Fig. 2) were found for Acropora, Cyphastrea, Leptastrea, Montipora, and Porites. The total number of genera per station varied between 0 and 15. When present (Haraiki, Nihiru, Marokau, Kauehi), pinnacles encompassed the highest number of genera, whereas in other lagoons where pinnacles were absent, the highest number of genera were found on the inner reef flat in front of motus and hoa, and on the lagoon floor (Fig. 2). Generic richness was also relatively high at stations located near passes, except at one station in Tepoto Sud (Te-PA2). Mean abundance was highly variable among the 58 stations (Fig. 2, Table 3), ranging from 0 to 18.7 colonies $\mathrm{m}^{-2}$, with high values generally found at pinnacle and pass stations (except station Te-PA2). Coral cover per station ranged between 0 to $39.6 \%$, and pinnacle stations were again characterized by high values.

A significant difference among habitats was found for all three descriptors (KW test, percent cover: $\chi^{2}=40.5, p<0.01$, abundance: $\chi^{2}=140.4, p<0.01$, generic richness: $\chi^{2}=$ $145.1, p<0.01)$. Coral generic richness, abundance, and cover were significantly higher at pinnacle stations than other habitats. Abundance and cover found at pass stations were also slightly higher than at rim, motu, floor or hoa stations. For these last four habitats, differences in generic richness, abundance and cover were low and generally not highly significant (Table 3).

Results of the CA performed on the abundance of the 24 genera recorded at the 54 stations are presented (Fig. 3). The cumulative percentage of variance of the first two axes was $35.2 \%$. There was considerable overlap in generic composition across stations of different lagoonal origin. Pass, pinnacle and floor stations, that were the richest and possessed most rare species (Table 3), were more discriminated by the first two axes than motu, hoa and rim stations. Stations from these last three habitats, that encompassed mostly common genera and only a few rare species (Montastrea and Millepora), tended to cluster together. There was significantly less co-occurrence than expected by chance (C-score: $p<0.05$; Table 4), however the number of checkerboards did not significantly deviate from random. The number of unique genera combinations was significantly lower than the number of combination expected by chance (Combo: $p=0.048)$. 

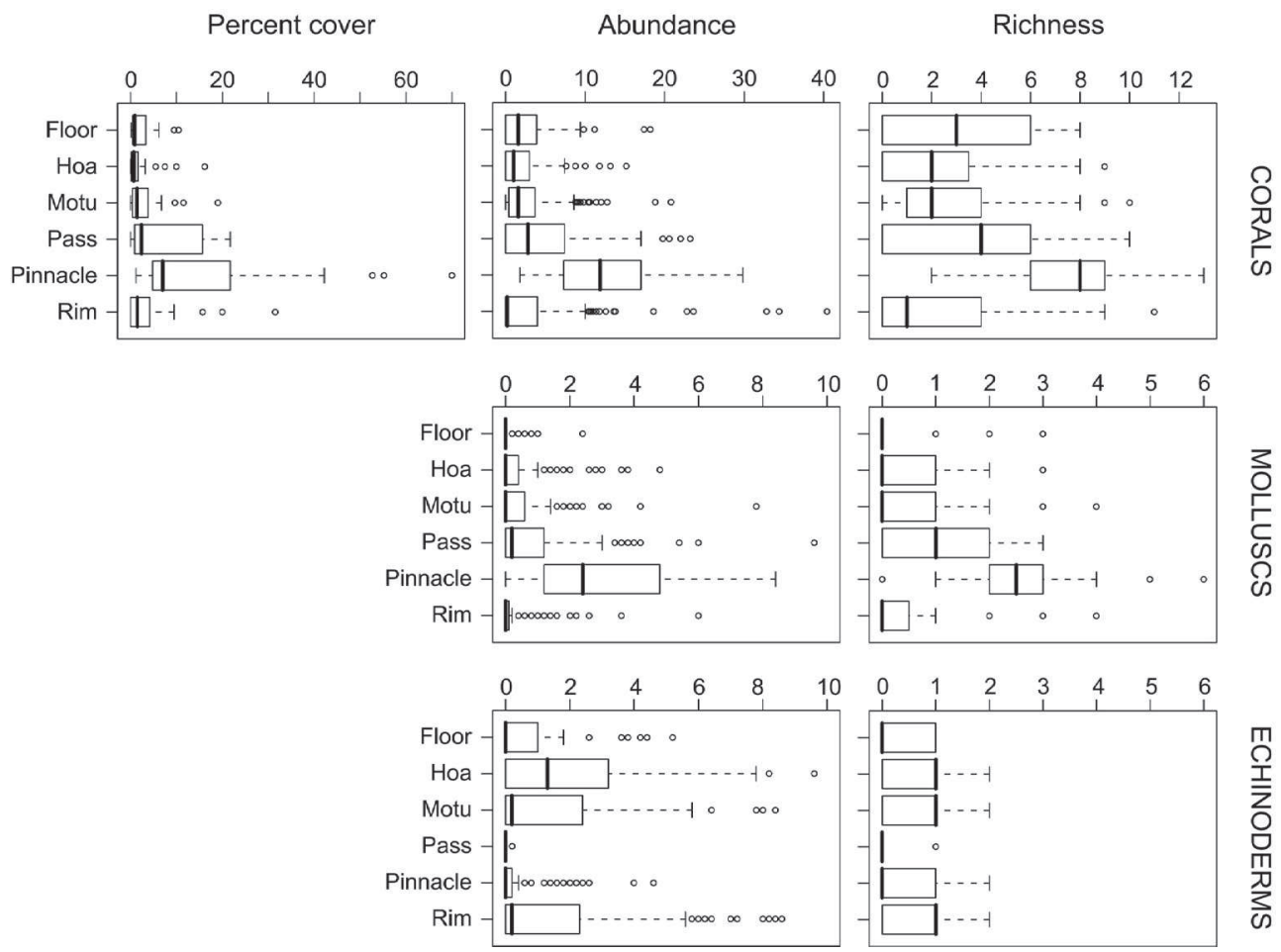

Fig. 2. Box-and-whisker plot of the mean generic or species richness, abundance, and percent cover of coral colonies, molluscs and echinoderms from the six habitats surveyed. Data of the same habitat pooled among lagoons. Richness is presented as the number of genera per quadrat for corals, and numbers of species per quadrat for molluscs and echinoderms. Abundance is presented as colonies $\mathrm{m}^{-2}$ for corals, and as numbers of individuals $\mathrm{m}^{-2}$ for molluscs and echinoderms.

Table 3. Summary of the Mann-Whitney tests performed on the mean generic richness (GR), species richness (SR), abundance $(\mathrm{AB})$ and percent cover among all pairs of the six habitats $(* * *: p<0.001$, $* *: p<0.01, *: p<0.05$, NS: non significant at the $95.0 \%$ confidence level).

\begin{tabular}{|c|c|c|c|c|c|c|c|}
\hline & \multicolumn{3}{|c|}{ Corals } & \multicolumn{2}{|c|}{ Molluscs } & \multicolumn{2}{|c|}{ Echinoderms } \\
\hline & GR & $\mathrm{AB}$ & \% Cover & SR & $\mathrm{AB}$ & SR & $\mathrm{AB}$ \\
\hline Floor - Hoa & $* *$ & NS & NS & ** & $* *$ & $* *$ & *** \\
\hline Floor - Motu & NS & NS & NS & $* * *$ & $* * *$ & NS & $* *$ \\
\hline Floor - Pass & NS & $*$ & NS & $* * *$ & $* * *$ & *** & $* * *$ \\
\hline Floor - Pinnacle & $* * *$ & $* * *$ & $* * *$ & $* * *$ & $* * *$ & NS & NS \\
\hline Floor - Rim & $* *$ & NS & NS & NS & NS & NS & $* *$ \\
\hline Hoa - Motu & $* *$ & $* *$ & NS & NS & NS & NS & $*$ \\
\hline Hoa - Pass & $* * *$ & $* * *$ & $*$ & $*$ & $* *$ & $* * *$ & $* * *$ \\
\hline Hoa - Pinnacle & $* * *$ & *** & $* * *$ & $* * *$ & $* * *$ & $* * *$ & $* * *$ \\
\hline Hoa - Rim & NS & NS & NS & $* *$ & $* *$ & NS & $*$ \\
\hline Motu - Pass & $*$ & $*$ & NS & NS & NS & $* * *$ & $* * *$ \\
\hline Motu - Pinnacle & $* * *$ & $* * *$ & $* * *$ & $* * *$ & $* * *$ & $* *$ & $* * *$ \\
\hline Motu - Rim & $* * *$ & $* *$ & NS & $* * *$ & $* * *$ & NS & NS \\
\hline Pass - Pinnacle & $* * *$ & $* * *$ & $*$ & $* * *$ & $* * *$ & $* * *$ & $* * *$ \\
\hline Pass - Rim & $* * *$ & ** & NS & **** & $* * *$ & **** & $* * *$ \\
\hline Pinnacle - Rim & $* * *$ & $* * *$ & $* * *$ & $* * *$ & $* * *$ & $* *$ & $* * *$ \\
\hline
\end{tabular}

\subsection{Molluscs}

Most macromollusc species were rare, with $70 \%$ of 27 species being found within one or two habitats (Table 2). Five species were commonly observed. Only Chama imbri-

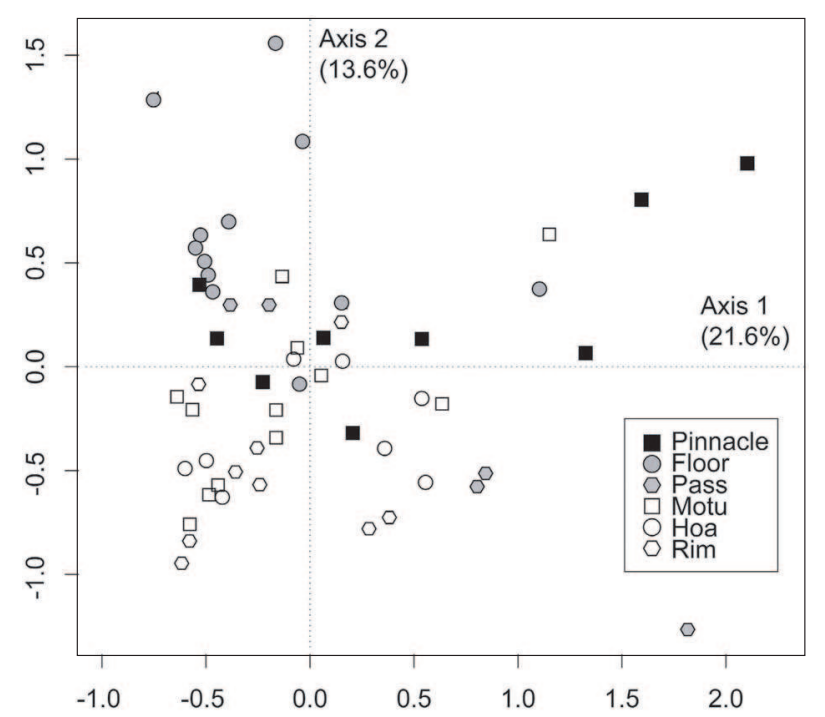

Fig. 3. Ordination plot of the correspondence analysis performed on the abundance of 24 genera recorded at the 54 stations (no corals were recorded at stations Tepoto-R1, Te-R2, Te-PA2, and Haraiki-R1). The first two axes explained $35.2 \%$ of the total inertia. Positions of stations along the first two axes are given.

cata and Tridacna maxima were ubiquitous. As with stony corals, mollusc species that were found within few habitats were also found within the lagoons of few atolls. For example, Conus pullicarius and $C$. rattus were only observed on rim 
Table 4. Summary of null model tests for deviation of presence-absence matrices from randomness. Index abbreviations - "C-score": checkerboard score; "Checker": number of perfect checkerboards; "Combo": number of species combinations. Simulated indices were generated from randomized matrices. The mean of simulated indices is presented here with its corresponding variance. P obs-: the probability that the observed statistic is less or equal to the simulated statistic; P obs+: the probability that the observed statistic is superior or equal to the simulated statistic; SE: Standardized Effect Size.

\begin{tabular}{|c|c|c|c|c|c|c|c|}
\hline Group & Index & Observed & Simulated & Variance & $P$ obs $^{-}$ & $P$ obst & SES \\
\hline \multirow[t]{3}{*}{ Corals } & C-score & 43.00 & 40.94 & 0.27 & 1.000 & 0.000 & 3.95 \\
\hline & Checker & 42.00 & 39.57 & 15.61 & 0.771 & 0.325 & 0.61 \\
\hline & Combo & 53.00 & 54.66 & 0.34 & 0.048 & 0.990 & -2.84 \\
\hline \multirow[t]{3}{*}{ Molluscs } & C-score & 8.64 & 8.72 & 0.09 & 0.431 & 0.576 & -0.27 \\
\hline & Checker & 249.00 & 232.93 & 16.64 & 1.000 & 0.000 & 3.94 \\
\hline & Combo & 39.00 & 37.55 & 1.21 & 0.892 & 0.278 & 0.91 \\
\hline \multirow[t]{3}{*}{ Echinoderms } & C-score & 20.11 & 18.51 & 0.89 & 0.943 & 0.062 & -1.70 \\
\hline & Checker & 15.00 & 17.72 & 1.50 & 0.036 & 0.997 & -2.22 \\
\hline & Combo & 15.00 & 15.01 & 1.21 & 0.672 & 0.675 & -0.01 \\
\hline \multirow[t]{3}{*}{ Macrobenthos } & C-score & 23.81 & 22.56 & 0.06 & 1.000 & 0.000 & 5.30 \\
\hline & Checker & 785.00 & 745.83 & 204.38 & 0.988 & 0.012 & 2.74 \\
\hline & Combo & 56.00 & 56.00 & 0.00 & 1.000 & 0.998 & 0.04 \\
\hline
\end{tabular}

stations of Kauehi (Table 2). A significant difference among habitats was found for both abundance and species richness (KW test, abundance: $\chi^{2}=175.8, p<0.01$, species richness: $\left.\chi^{2}=160.3, p<0.01\right)$. Abundance ranged from 0 to 11.8 individuals $\mathrm{m}^{-2}$, and richness ranged from 0 to 6 species per quadrat. Abundance and richness were highest at pinnacle stations (Fig. 2). There was a significant difference between these stations and all others, for both descriptors (Table 3). Stations from the floor and rim, hoa and motu, and motu and pass were statistically identical in terms of abundance and species richness. The number of checkerboards (species pairs that never co-occur) was higher than expected by chance $(p<0.05)$, indicating segregation. However, the number of unique species pair and the C-score were not statistically different from random species association (Table 4).

\subsection{Echinoderms}

Among the 8 species of echinoderms encountered, 3 were rare, 5 were common, and none were ubiquitous at the habitat scale. Similar to corals and molluscs, but to a lesser extent, species that were found within a few habitats were also found within lagoons of a few atolls. Highest echinoderm diversity was observed at hoa, motu and rim stations. Actynopyga mauritiama and Linckia multiflora were found exclusively within pinnacle (Nihiru) and motu (Marokau) stations, respectively. The holothurian Holothuria atra was the only echinoderm species found on floor stations, and both were widely distributed among habitats and atolls (Table 2). A significant difference among habitats was found for both descriptors (KW test, abundance: $\chi^{2}=102.7, p<0.01$, species richness: $\left.\chi^{2}=85.4, p<0.01\right)$. Abundance ranged from 0 to 9.6 individuals $\mathrm{m}^{-2}$, and richness ranged from 0 to 2 species per quadrat. Hoa stations sheltered the most individuals, and the habitat was statistically different from all others (Table 3). Whereas mean abundances were similarly low for all habitats but hoa, variance was higher for motu and rim stations. Passes sheltered no echinoderms in general, with a few exceptions (individuals were found within $4 \%$ of all pass quadrats). Motu, rim and hoa stations sheltered the highest numbers of species per quadrat. Finally, there was no evidence suggesting that species co-occurrence follows a non-random pattern (Combo, Checker, C-score: $p>0.005$; Table 4).

\subsection{Macrobenthos}

Similar patterns of station association were observed on the CA plot for corals and pooled benthic organisms (Fig. 4). The cumulative percentage of variance of the first two axes was $30.8 \%$. Stations from hoa, motu and rim tended to cluster together. As with corals, there was significant overlap between stations of different lagoonal origin. The CA plot for macrobenthos was strongly arched. Co-occurrence simulations suggest a significant deviation from random association, toward segregation. The $\mathrm{C}$-score and the Checker indices were both significantly higher than expected $(p<0.05)$. However, the number of genera/species combinations was not $(p>0.05$; Table 4).

\section{Discussion}

\subsection{Spatial patterns of benthic invertebrate assemblages}

Our results showed a strong disparity in benthic invertebrate assemblages among the different habitats found in atoll lagoons. For stony corals, the marked small-scale spatial heterogeneity within lagoons appears to be one of the distinctive characteristics of French Polynesian coral communities (Adjeroud 1997), and complements similar results found at the same scale on high volcanic islands (Adjeroud 1997, 2006). 


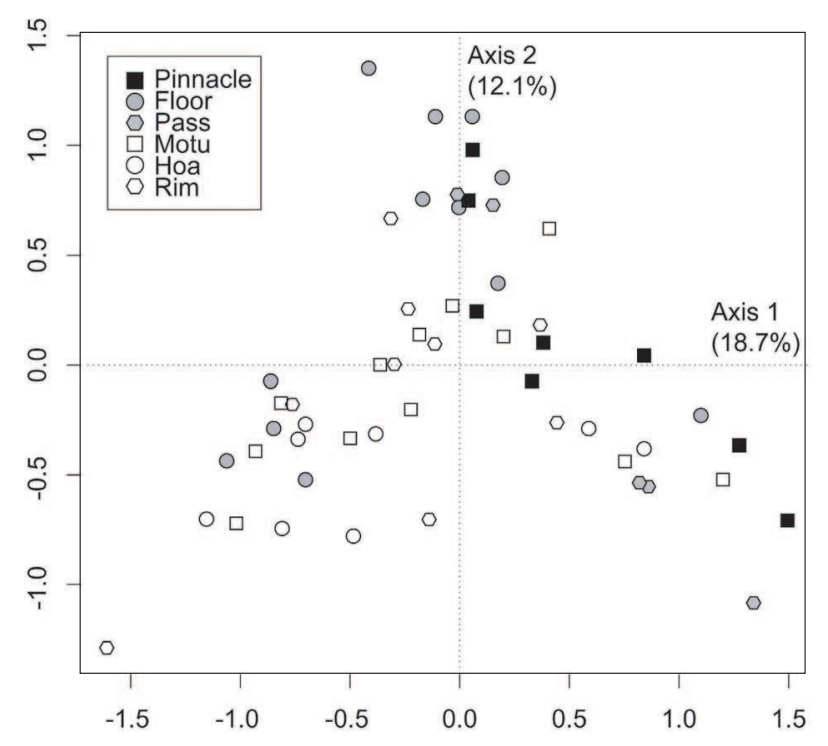

Fig. 4. Ordination plot of the correspondence analysis performed on the abundance of 59 genera and species (three taxonomic groups pooled, or "macrobenthos") recorded at the 54 stations (no coral, mollusc or echinoderm were recorded at stations Tepoto-H1, Te-H2, Haraiki-C1; moreover, station Tepoto-PA2 was made passive, as it was responsible for the compression of all other stations at the center of the ordination space). The first two axes explained $30.8 \%$ of the total inertia. Positions of stations along the first two axes are given.

Within lagoon variations in benthic assemblages has been previously observed in the Pacific (e.g., Canton Atoll: Jokiel and Maragos 1978; Johnston Atoll: Jokiel and Tyler 1992; French Frigate Shoals, Northwestern Hawaiian Islands: Vroom et al. 2005; Kenyon et al. 2006). The intra-lagoonal variation also complements the inter-lagoonal variation found in Tuamotuan atolls (Adjeroud et al. 2000). This outcome is consistent with findings of recent studies that clearly demonstrated the importance of both local and regional factors in determining the diversity and structure of coral assemblages and the sensitivity of local coral richness to environmental variation across depth and habitat gradients (Cornell and Karlson 1996; Karlson and Cornell 1998; Rajasuriya et al. 1998; Bellwood and Hughes 2001; Karlson et al. 2004). The combination of the present study and Adjeroud et al.'s (2000) emphasizes the importance of nested spatial scales in structuring benthic invertebrate communities.

Molluscs and echinoderms were less abundant and less diverse than stony corals. This under-representativeness was also observed on high volcanic islands in French Polynesia (Adjeroud 1997, 2000). While the low diversity of molluscs may be partly explained by the methodology (only the presence of individuals $>1 \mathrm{~cm}$ was recorded; the cryptic fauna was not sampled), the overall low diversity of echinoderms in French Polynesia (30 species, Richard 1985) may explain the patterns observed in this study (see also Adjeroud 2000).

Null model simulations gave evidence that corals, molluscs, and all taxonomic groups pooled (macrobenthos) significantly deviated from random association. The co-occurrence of corals was not so much explained by genera that never co-occurred together, but rather by pairs that tended to co- occur significantly less than expected by chance (C-score and Combo: $p<0.05$; Checker: $p=0.3$ ). There was some evidence that the mollusc community is structured by competitive interactions, as the number of species pairs was significantly larger than expected by chance. However, this result should be interpreted with care, as the Checker is subject to Type I error (Gotelli 2000), and the C-score, which is a more statistically robust descriptor of co-occurrence (Gotelli 2000), did not significantly deviate from random. Finally, there was no reason to reject the null hypothesis that patterns of echinoderm cooccurrence are not different than what would be observed for a non structured assemblage, as all indices were non significant.

Among the six habitats defined during the initial phase of the TYPATOLL program, pinnacles were clearly the most distinguishable for corals and molluscs, with the maximum generic richness, mean abundance and coverage of colonies/individuals. However, there were no characteristic genera associated with this habitat. Our quantitative data confirm for the first time qualitative observations suggesting that pinnacles in French Polynesia provide a favorable habitat for coral diversity and growth (Faure and Laboute 1984; Harmelin-Vivien 1985). At French Frigate Shoals (Hawaiian Islands), Vroom et al. (2005) found that benthic assemblages on the investigated pinnacle were strongly differentiated and constituted a separate "ecozone". We hypothesize that the steep slopes of pinnacles probably reduce sedimentation and thus offer an adequate substrate for settlement of coral colonies and other reef invertebrates. Other factors that may favor coral growth and diversity are enhanced water flow and gradation in light intensity. As such environmental conditions are likely to vary along pinnacles, high diversity of corals and molluscs might be the result of an edge effect at a small spatial scale (Goreau and Wells 1967; Porter 1972). In the context of the endo-upwelling theory of pinnacle growth, Guilcher (1991) argued that pinnacles, located at places where sets of fissures end in the bottom of the lagoon, may favor surrounding productivity, which in turn, stimulates coral growth. Guilcher described pinnacles as "outlets of feeders by which the atoll ecosystem is maintained". However, further investigations are now needed to understand why this habitat is so favorable for coral richness and abundance.

Passes were also distinct, with abundance, richness (corals and molluscs) and coverage (corals) values slightly higher than the lagoon floor, hoa, motu and rim habitats. The same pattern was observed in Canton atoll lagoon for corals (Jokiel and Maragos 1978). We hypothesize that the greater size of coral assemblages at passes is partly explained by the high hydrodynamic conditions found at the vicinity of passes, which reduce sedimentation, and thus favor the establishment of more colonies. Moreover, passes may represent a transitional habitat, or ecotone, between the rest of the atoll lagoon and the outer reef slope. This last, which was documented as the place of highest coral diversity and abundance in French Polynesian reefs (Adjeroud 1997), may also constitute a source of colonizers in the vicinity of the pass.

In contrast, we found no difference between the lagoon floor, hoa, motu and rim in term of generic richness, abundance and percent cover of stony corals, and similar patterns were observed on mollusc abundance and richness. Coral 
assemblages of the lagoon floor were slightly distinct because of the higher abundance of Astreopora and Lobophyllia and by the occurrence of Echinopora in some lagoons. This outcome is consistent with previous surveys, which have demonstrated that some species of Echinopora and Astreopora are well adapted to environmental conditions found in lagoon floor habitat (i.e., lower light, high sedimentation; McClanahan and Obura 1997). The lack of marked differences between rim, hoa and motu may indicate that environmental conditions are not sufficiently different among these geomorphological features for the establishment of distinct coral assemblages. Sedimentation, paucity of adequate substrate, and high daily variation in water temperature (reef flats in front of submerged rim, motu and hoa were not deeper than $5 \mathrm{~m}$ ) may also explain the reduction in generic richness, abundance and percent cover of corals found there.

While the zonation of coral and mollusc assemblages was very similar, the highest abundance and richness of echinoderms were found among stations of different lagoonal origin. Indeed, maximum richness and abundance was recorded on the inner reef flat in front of spillways (hoa) and along the rim, where minimum values were recorded for corals and molluscs. Additionally, pass and pinnacle sheltered the fewest echinoderm species and individuals, contrary to the two other taxonomic groups investigated. This zonation pattern may be attributed to the different habitat requirement of echinoderms, which are primarly represented by grazers.

\subsection{Recommendations for MPA design}

The results of this study demonstrate that geomorphological features of atoll lagoons influence the structure and spatial heterogeneity of benthic invertebrate communities. As underlined by Vroom et al. (2005), habitat heterogeneity contributes to maintaining biological diversity (Levin 1974; Huston 1979; Diamond 1988), making atoll lagoons areas of particular interest for marine conservation. Among the six habitats distinguished a priori during the sampling design of the TYPATOLL program (Dufour and Harmelin-Vivien 1997), our results showed that four of these six habitats encompass distinct coral and mollusc communities. Habitat delineation was different for echinoderms, principally aggregated on hoa, motu and rim stations.

The design of marine reserves should ensure that the full spectrum of biodiversity is protected (representativeness), as well as its long-term persistence, involving spatial and temporal dynamics of population connectivity (Cabeza and Moilanen 2001; Cabeza et al. 2004). Even though habitat groups were defined in terms of abundance, cover and richness as structured, non-randon associations, species did not show strong fidelity to particular groups across atoll lagoons. Indeed, there was a clear relationship between representativeness at the habitat scale and the atoll scale (see Table 2), and it is challenging to predict specific/generic occurrence (Micheli and Halpern 2005). Thus, protecting either entire atolls as a source population for others, or portions of distinctive habitats within a set of atolls is not likely to capture the full spectrum of biodiversity. Indeed, our survey revealed that for all three taxonomic groups, there were many species that were rare, both at the habitat and lagoon scale. Therefore, if maintaining biodiversity is a primary goal, it is likely that conservation of French Polynesian atoll lagoons based on the sole criterion of full representativeness might require selecting the vast majority of lagoonal habitats, for all lagoons concerned. This strategy, however, is not pragmatic and is very likely to violate economic and social MPA design criteria, such as compatibility with existing use of lagoonal resources (Roberts et al. 2003). Indeed, there is an existing history of conflict between the French Polynesian governments' will to implement marine reserves, native Polynesians' claim to traditional rights and access to local marine resources, and the tourism industry (Vieux et al. 2004). Protecting lagoons possessing higher biodiversity might constitute a more pragmatic strategy. Ironically, those atolls possessing more biological diversity tend to be the largest (Adjeroud et al. 2000), and sustain larger human populations (Table 1). The degree of communication between lagoon and oceanic waters might therefore be a more valuable criterion in reserve site selection if high biodiversity is a primary conservation goal.

Determining the connectivity between atoll lagoon communities will soon become critical knowledge in terms of resource protection. Indeed, atolls vary in their degree of openness to oceanic waters, and Adjeroud et al. (2000) demonstrated that physical characteristics of the atoll correlate with the differentiation of lagoonal communities. Because of variability in lagoonal openness, similarity between benthic invertebrate communities of separate lagoons could be interpreted as an index of connectivity. In the light of our results, we hypothesize that benthic invertebrate communities within atoll lagoons are in fact meta-communities, who's taxonomic compositions are due a combination of random colonization events (Sale 1977), pre-emptive competition and differential survivorship. The degree to which atoll lagoon assemblages behave as meta-communities nested within the Tuamotu Archipelago remains an important question, and connectivity patterns may be further investigated as new genetic markers are being developed. In conclusion, we stress the need to integrate the strong heterogeneity in benthic community structure at small, nested spatial scales into the conservation planning of French Polynesian atoll lagoons.

Acknowledgements. This study was carried out within the framework of the program "TYPATOLL" (Institut de Recherche pour le Développement, Programme National sur les Récifs Coralliens, Territoire de la Polynésie française). This paper is a contribution to the program undertaken with the research unit "CoRéUs" (IRD) on the biocomplexity of coral reef ecosystems. The assistance of the officers and crew of RV "Alis" and the staff of TYPATOLL is gratefully acknowledged. The authors wish to thank the program "CoRéUs" (IRD) for contributing to this paper, and J. Ferraris, T. Hughes, P. Sale, C. Gonzales, A. Viricel, and anonymous reviewers for their critical comments on the previous drafts.

\section{References}

Adjeroud M., 1997, Factors influencing spatial patterns on coral reefs around Moorea, French Polynesia. Mar. Ecol. Prog. Ser. 159, 105-119. 
Adjeroud M., 2000, Zonation des communautés macrobenthiques le long de deux baies d'un écosystème corallien insulaire (Moorea, Polynésie française). C. R. Acad. Sci. Paris, série III, 323, 305-313.

Adjeroud M., 2006, Zonation of coral assemblages in the Ryukyu Islands (southern Japan): the importance of land-ocean gradients and reef habitats. Proc. 10th Int. Coral Reef Symp., pp. 310-318.

Adjeroud M., Andréfouët S., Payri C., Orempuller J., 2000, Physical factors of differentiation in macrobenthic communities between atoll lagoons in the Central Tuamotu Archipelago (French Polynesia). Mar. Ecol. Prog. Ser. 196, 25-38.

Agardy M.T., 1994, Advances in marine conservation: The role of marine protected areas. Trends Ecol. Evol. 9, 267-270.

Bellwood D.R., Hughes T.P., 2001, Regional-scale assembly rules and biodiversity of corals reefs. Science 292, 1532-1534.

Bouchon C., 1983, Les peuplements de scléractiniaires de l'atoll de Takapoto (Polynésie Française). J. Soc. Océan. 39, 35-42.

Cabeza M., Moilanen A., 2001, Design of reserve networks and the persistence of biodiversity. Trends Ecol. Evol. 16, 242-248.

Cabeza M., Moilanen A., Possingham H.P., 2004, Metapopulation dynamics and reserve network design. In: Hanski I., Gaggiotti O.E. (Eds.) Ecology, Genetics, and Evolution of Metapopulations, Elsevier Academic Press, pp. 541-564.

Chevalier J.P., Denizot M., 1979, Les organismes constructeurs de l'atoll de Takapoto. J. Soc. Océan. 35, 31-34.

Cornell H.V., Karlson R.H., 1996, Species richness of reef-building corals determined by local and regional processes. J. Anim. Ecol. $65,233-241$.

Diamond J.M., 1975, Assembly of Species Communities. In: Cody M.L., Diamond J.M. (Eds.) Ecology and Evolution of Communities, Harvard, Belknap, pp. 342-444.

Diamond J.M. 1988, Factors controlling species diversity: overview and synthesis. Ann. Missouri Bot. Gard. 75, 117-129.

Dufour P., Harmelin-Vivien M., 1997, A research program for a typology of atoll lagoons: strategy and first results. Proc. 8th Int. Coral Reef Symp., 1, pp. 843-848.

Faure G., Laboute P., 1984, Formations récifales 1: Définition des unités récifales et distribution des principaux peuplements de scléractiniaires. In: L'atoll de Tikehau (archipel des Tuamotu, Polynésie Française) premiers résultats. ORSTOM Tahiti, Notes Doc. Océanogr. 22, 108-136.

Gerber L.R., Botsford L.W., Hastings A., Possingham H.P., Gaines S.D., Palumbi S.R., Andelman S., 2003, Population models for marine reserve design: a retrospective and prospective synthesis. Ecol. Appl. 13, S47-S64.

Goreau T., Wells J., 1967, The shallow-water scleractinia and their vertical distribution range. Bull. Mar. Sci. 17, 442-453.

Gotelli N.J., 2000, Null model analysis of species co-occurrence patterns. Ecology 81, 2606-2621.

Gotelli N.J., Graves G.R., 1996, Null Models in Ecology. Washington, Smithsonian Institution Press.

Gotelli N.J., Arnett A.E., 2000, Biogeographic effects of red fire ant invasion. Ecol. Lett. 3, 257-261.

Gotelli N.J., McCabe D.J., 2002, Species co-occurrence: a metaanalysis of J.M. Diamond's assembly rules model. Ecology 83, 2091-2096.

Gotelli N.J., Entsminger G.L., 2006, EcoSim: Null models software for ecology. Version 7. Acquired Intelligence Inc. \& Kesey-Bear. Jericho, VT 05465. http://garyentsminger. com/ecosim.htm.

Guilcher A., 1991, Progress and problems in knowledge of coral lagoon topography and its origin in the South Pacific, by way of pinnacle study. From Shoreline to Abyss, SEPM Spec. Publ. 46, 173-188.
Gurevitch J., Morrow L.L., Wallace A., Walsh J.S., 1992, A metaanalysis of field experiments on competition. Am. Nat. 140, 539-572.

Harmelin-Vivien M., 1985, Tikehau atoll, Tuamotu archipelago. Proc. 5th Int. Coral Reef Symp., 1, pp. 211-268.

Haukisalmi V., Henttonen H., 1998, Analysing interspecific associations in parasites: alternative methods and effects of sampling heterogeneity. Oecologia 116, 565-574.

Holland D.S., Brazee R.J., 1996, Marine Reserves for Fisheries Management. Mar. Resour. Econ. 11, 157-171.

Huston M. 1979, A general hypothesis of species diversity. Am. Nat. 113, 81-101.

Hutchings P., Payri C., Gabrie C., 1994, The current status of coral reef management in French Polynesia. Mar. Pollut. Bull. 29, 26-33.

Jokiel P.L., Maragos J.E., 1978, Reef corals of Canton Atoll: II. Local distribution. Atoll Res. Bull. 221, 72-97.

Jokiel P.L., Tyler W.A. 1992, Distribution of stony corals in Johnston Atoll Lagoon. Proc. 7th Int. Coral Reef Symp., 2, pp. 22-26.

Karlson R.G., Cornell H.V., 1998, Scale-dependent variation in local vs. regional effects on coral species richness. Ecol. Monogr. 68, 259-274.

Karlson R.G., Cornell H.V., Hughes T.P., 2004, Coral communities are regionally enriched along an oceanic biodiversity gradient. Nature 429, 867-870.

Kenyon J., Vroom P.S., Page K.N., Dunlap M.J., Wilkinson C.B., Aeby G.S. 2006, Community structure of hermatypic corals at French Frigate Shoals, Northwestern Hawaiian Islands: capacity for resistance and resilience to selective stressors. Pacific Sci. 60, 153-175.

Legendre P., Legendre L., 1998, Numerical ecology. Amsterdam, Elsevier Science B.V.

Levin S.M. 1974, Dispersion and population interactions. Am. Nat. 108, 207-228.

Loya Y., 1972, Community structure and species diversity of hermatypic corals at Eilat, Red Sea. Mar. Biol. 13, 100-123.

McClanahan T.R., Obura D., 1997, Sedimentation effects on shallow coral communities in Kenya. J. Exp. Mar. Biol. Ecol. 209, 103-122.

Micheli F., Halpern B.S., 2005, Low functional redundancy in coastal marine assemblages. Ecol. Lett. 8, 391-400.

Ogden J.C., 1997, Marine managers look upstream for connections. Science 278, 1414-1415.

Pielou D.P., Pielou E.C., 1968, Association among species of infrequent occurrence: the insect and spider fauna of Polyporus betulinus (Bulliard) Fries. J. Theor. Biol. 21, 202-216.

Porter J., 1972, Patterns of species diversity in Caribbean reef corals. Ecology 53, 745-748.

R Development Core Team, 2003, R: A language and environment for statistical computing. R Foundation for Statistical Computing, Vienna, Austria. URL. http://www.R-project.org.

Rajasuriya A., Öhman M.C., Svensson S., 1998, Coral and rock reef habitats in Southern Sri Lanka; patterns in the distribution of coral communities. Ambio 27, 723-728.

Richard G., 1985, Fauna and flora, a first compendium of French Polynesian sea-dwellers. Proc. 5th Int. Coral Reef Cong. 1, pp. 379-520.

Roberts C.M., 1997, Connectivity and management of caribbean coral reefs. Science 278, 1454-1457.

Roberts C.M., 1998, Sources, sinks, and the design of marine reserve networks. Fisheries 23, 16-19. 
Roberts C.M., Andelman S., Branch G., Bustamante R.H., Castilla J.C., Dugan J., Halpern B.S., Lafferty K.D., Leslie H., Lubchenco J., McArdle D., Possingham H.P., Ruckelshaus M., Warner R.R., 2003a, Ecological criteria for evaluating candidate sites for marine reserves. Ecol. Appl. 13, S199-S214.

Roberts C.M., Branch G.S., Bustamante R.H., Castilla J.C., Dugan J., Halpern B.S., Lafferty K.D., Leslie H., Lubchenco J., McArdle D., Ruckelshaus M., Warner R.R., 2003b, Application of ecological criteria in selecting marine reserves and developing reserve networks. Ecol. Appl. 13, S215-S228,

Sala E., Aburto-Oropeza O., Paredes G., Parra I., Barrera J.C., Dayton P.K., 2002, A general model for designing networks of marine reserves. Science 298, 1991-1993.

Sale P.F., 1977, Maintenance of high diversity in coral reef fish communities. Am. Nat. 978, 337-359.

Salvat B., 1983, La faune benthique du lagon de l'atoll de Scilly, archipel de la Société. J. Soc. Océan. 39, 3-15.

Salvat B. Aubanel A., 2002, La gestion des récifs coralliens de Polynésie française. Rev. Ecol. 57, 193-251.
Stevens T., 2002, Rigor and representativeness in marine protected area design. Coast. Manage. 30, 237-248.

Stevens T., 2005, Scales of similarity in soft sediment epibenthic assemblages: implications for marine protected area design. Mar. Biol. 146, 345-354

Stone L., Roberts A., 1990, The checkerboard score and species distributions. Oecologia 85, 74-79.

Vieux C., Aubanel A., Axford J., Chancerelle Y., Fisk D., Holland P., Juncker M., Kirata T., Kronen M., Osenberg C., Pasisi B., Power M., Salvat B., Shima J., Vavia V., 2004, A century of change in coral reef status in Southeast and Central Pacific: Polynesia Mana Node, Cook Islands, French Polynesia, Kiribati, Niue, Tokelau, Tonga, Wallis and Futuna. In: Wilkinson C. (Ed.) Status of Coral Reefs of the World 2004, Global Coral Reef Monitoring Network, Townsville, Australian Institute of Marine Science, pp. 363-380.

Vroom P., Page K., Peyton K., Kukea-Shultz J., 2005, Spatial heterogeneity of benthic commnunity assemblages with an emphasis on reef algae at French Frigate Shoals, Northwestern Hawai'ian Islands. Coral Reefs 24, 574-581. 